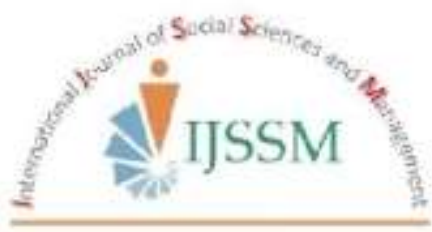

International Journal of Social Sciences and Management

Mini Review

\title{
VOCATIONAL EDUCATION AND TRAINING GRADUATES: CHALLENGES IN PRACTICAL SKILLS TO THE JOB MARKET
}

\author{
Basanti Roshan Pradhan Shrestha \\ Research and Development Department, Training Institute for Technical Instruction, Sanothimi, Bhaktapur, Nepal \\ Email: brs@ titi.org.np/brsshrestha@yahoo.com
}

\begin{abstract}
The purpose of this study is to describe the challenges facing vocational education and training graduates to the job market. Many studies and research has been done to identify the causes of the problem that vocational graduates are facing after they employed in the job market. But still problems are existing in job market as vocational graduates are facing difficulties to transfer their learning. Hence, it challenges the vocational Education and training system. Therefore, this study also focused on the possible interventions to solve the existing problems that vocational graduates and job markets have been facing. The gap and weak linkage between vocational training providers and job market challenges curriculum design and performance in job. So, Competency based training based curriculum design improve the quality of instruction through experienced instructors and training providers are the possible intervention to fill the gap.
\end{abstract}

Key words: Vocational education and training; Competency based training; Job market; Vocational instructor

\section{Introduction}

Vocational Education and Training (VET) refers to education and training that focuses on delivering skills and knowledge required for specific industries (State of Queensland, 2015). VET is the part of tertiary education and training which provides accredited training in job related and technical skills. It covers a large number of careers and industries like trades and office work, retail, hospitality and technology that is required by the industry. The courses offer as per the demand and the need of the people especially in the field of agriculture, engineering, health, tourism management and computer. Specially most of institute have been running mushroom production, mushroom production, gardening, cooking/baking housekeeping etc (Council for Technical Education and Vocational Training [CTEVT], 2012). The aim of providing certain professional and vocational skills to the people who are unable to gain higher education or are interested to gain certain vocational/professional skills for their better professional career (CTEVT, 2011).

Many Government semi-Government, private sectors, NGOs and INGOs offering vocational education and trainings producing semi-skilled and skilled workforce through VET trainings. Any person can enroll in VET course through TEVT institutions or vocational institutes by government non-government or private training providers.
In addition, many developed and developing countries has been providing vocational education and training in various trades.

The course designed to deliver workplace-specific skills and knowledge. VET covers a wide range of careers and industries, including trade and office work, retail, hospitality and technology. Individuals can be trained in part qualifications or skills sets. VET programs provide an education that directly relates to getting a job. VET courses are typically shorter and more practical than higher education courses and have an industry and trade focus related to the job market.

As VET focus on skill oriented that is also known as skill based training. This training to concentrate on developing and applying specific skills and behaviors. Learners must spend the majority of their training time engaged in learning, developing, and practicing skills in a variety of hands-on, real-life scenarios. After completing the VET courses and trainings, the skill worker should be able to perform the task independently and perform a wide variety of task in a different work environment and mediate between planning, execution and processes. The ultimate objective of skills training is to not only enable the learner to acquire proficiency in the skill, but have the confidence to competently apply it on the job. 
A vocational education also prepare people for a career that is based in manual practical activities and focused on specifically on a skill. It is also referred to as Career and Technical Education as it can help to develop a particular group of techniques and become proficient in a particular technology (Basnet, 2012).

However, even though the well-designed course and trainings has been designed the problem in the current situation is that industries are suffering from the unskilled workers. The problem today with many workplace training program is partially successfully in solving learning process because training is separated from the industrial success (Educational International, 2009). Training factor that impact on the transfer include insufficient time for learning and practice learning experiences that will designed and implemented.

\section{Challenges}

A survey of Asian Development Bank [ADB], (2014) shows that TVET programs are not based on industry and job market needs. One of the biggest problem is the lack of coordination between industry and training providers. Instead of forming coordination to plan and direct change caused by rapidly changing technology training providers are disconnected with the labor market (Gajural and Ghimire, 2012). The progress can only achieved if healthy coordination are developing for desired productivity (Lamsal 2012). Likewise, training providers do not design and implement job-oriented trainings. Training providers do not have industry-experienced instructors to provide good instruction. Training programs and curriculum do not specify the requirement of the job market. Similarly, the employers also identified deficiencies in teamwork, attitude, honesty, and work discipline of graduates.

The training curricula are rigid and are not regularly updated as per the changing needs of the labor market (Lamsal, 2012). Old and inflexible training curricula are not able to respond to the rapidly changing requirements of the labor market. The centralized decision making obstructs an immediate response to the emerging local human resource needs. The centralized management system puts too many restrictions on introducing new programs or revising the old ones.

Other constrains to effective VET instructors are delivery is the lack trained instructors and lack of capacity to train instructors (Andersson and Kopson, 2015).Some instructors have received little pedagogical training, including competency-based training but have few practical skills and possess little or no industry experience. Opportunities for instructors to train are limited. The supply of instructors has not matched the expansion in number of institutions, particularly in private sector and they are tend to employ untrained instructors.
Similarly, the career paths in some VET institutions are not clearly defined (Education International, 2009) For example, there is lack of upgrading in-service instructors. No continuing staff development is available to address deficiencies in instructor qualifications. The system offers very few opportunities for training and upgrading of skills of existing instructors. No policy or regulations exist requiring in-service training. There is neither a formal policy nor guidelines for continuous professional developments of instructors while other who have developed guidelines but did not implement effectively (ADB, 2014).

Likewise, there is a question of permanent requirement of instructors and most of them are on contract basis which also decline the motivation and quality training delivery. Training provision tends to be largely supply driven, based on the allocated budgets of public training providers and available staff and equipment. Most of the training programs are designed based on the available instructor, equipment, and facilities within the training institutes without considering the changing demand of skills and labor market needs (Lamsal, 2012). This forced instructors to limit on theoretical sessions and as a result graduates are not skillful in their field which effects the job market.

In some cases, instructors were not sufficiently trained in practical work. They had academic and occupational training in their trade but not enough practice and skills to deliver the VET programs (CTEVT, 2011). Andin and Ambotang (2015) found that instructor also do not have industrial experiences. This experience enable instructors to deliver and assess VET programs relevant to current industry practices. In addition, it was realized that the class sizes of training room do not match with the supply and provision of training resources (Idiali, 2014). This does not allow the instructor to attract and retain the attention of all learners during demonstration and practical activities according to the new curricula, using a competency-based teaching approach. The instruction focus on task oriented, problem solving that generally occurs in workplace when the worker learn how to improve job performance, demonstration an applied context, aiming and reinforcing academic skills that is doing good job in skills.

\section{Possible Interventions}

First of all the better understanding and the coordination of VET training providers and labour market is important (Education International, 2009). According to Zinser and Lawrenz (2004) the VET providers have now more open to the involvement of industry experts, to streamline their curriculum development process and to seek out professional development opportunities. To fill the gap and to solve the problem, both the industry and training providers have now the same goal to educate and employ new technicians. 


\section{Competency Based Training (CBT)}

Competency-based training (CBT) is an approach to VET that emphasis on what person can do in the workplace as a result of completing the training program .CBT is focused on competencies that are inked to work force needs defined by industry. In CBT learners can learn by carefully designed learner centered activities, varieties of media and methods in each task. Materials are organized in such a way that individual can stop, repeat, slow down, speed up instruction with sufficient time as needed to learn effectively (Blank, 1982).

Competency standards are industry-determined specifications of performance that set out the skills, knowledge and attitudes required to operate effectively in a specific industry or profession. Competency standards are made up of units of competency, are which made up of elements of competency, together with performance criteria, a range of variables, and an evidence guide. Competency standards are an endorsed component of a training package (TAFE, 2008). In CBT learners can assessed by ability to perform task and duties expected standard. CBT also focuses on development of skills, knowledge and attitudes required to achieve competency standards. This is vital for both instructor and learners and to achieve the learning outcomes takes lots of practice (International Confederation of Midwifes [ICM], 2012).

Competencies within different context may require different skills, knowledge and attitudes. CBT can reshape teaching and learning in ways relevant to industry demands. CBT training packages prescribe the competency or the skills, knowledge and attributes required for effective performance in the workplace.

Acakpovi and Nutassey (2015) found that the CBT program improves job accessibility. It also provides many other advantages including increase practical activities, effective capacity building and linkages with industry which results in easy job placement. For these reasons that the CBT system is fully adopted in many countries that are conducting VET courses.

\section{CBT Curriculum}

The quality of VET program depend upon the curriculum if it is designed developed and implemented in right way that achieve the desired objectives acquired by the industry. Curriculum which is designed to stimulate learning and reinforces curriculum is based upon a thematic approach which engages the interest of all learners. The curricula development in the emerging technology could help in developing human resources in that area. Timely revision of the curricula plays a vital role to fill the gap in changing technology of labour market (Gajurel and Ghimire, 2012).
According to Blank (1982), the good CBT curriculum is based on the following points and training providers should consider when designing curriculum.

1. Before designing VET training course, market needs to be identified.

2. The duties and task of occupation should be analyzed and identified with subject matter experts.

3. The objectives (Terminal performance objectives) of each task should be developed. This will describe the under which condition performance is demonstrated, time required to performing task and standard of the task. Course standards should be appropriate to the target group and meet with job market.

4. Develop performance test to evaluate acquired task in the training program. Likewise, develop knowledge test to assess the concept or fact that underlying the task. Courses must include appropriate assessment approaches to assess the training standards.

5. Develop training materials or training packages like visuals and lesson plan and assignments. The VET course must design flexible and varieties of approaches to delivery.

6. The curriculum should revise periodically as per change in technology of the job market.

\section{Soft skills}

Employer with degree or specific occupation needs a basic set of professional skills and attitudes for long term success of the industry. Worker's technical skills or hard skills can be learnt, apply and measure to required standard but same cannot be applied for the soft skills. Soft skills are not directly taught in training programs. But both skills are very important for VET courses .Soft skills plays an important role in job and are highly prioritized and required in a job (Ngang et al., 2014). Therefore, the VET institution when design their curriculum and instruction, should not forget to incorporate the soft skills like team work, problem solving ,sharing task, group discussion, sharing information ,communication skills in order to achieve the objective that is related to industry. Soft skills can be identified during the subject matter expert (SME) workshop of task analysis of curriculum development where necessary soft skills for particular task can be identified and incorporated in curriculum (Neupane and Pradhan 2014).

\section{Training providers}

The environment of training institute has strong influence in teaching learning process because the learning takes place when learning environment is well organized, motivating and peaceful. In addition, the training should deliver in such way that give learners the ability to transfer their learning to job application and the training instructions 
matches the job requirement. Teaching learning materials, hands on practical tools and equipment plays vital role in transferring knowledge and skills the job (Gajurel and Ghimire, 2012).Therefore, for teaching effectively there should be provision of facilities in terms of space, equipment, tools, machine, materials and instructional materials to acquire desired knowledge and skills. Sufficient classroom, workshop, labs and field should be provided to support learner to gain practical experiences in the training (Idiali, 2014). The learning environment, course and program should be supervised by management to maintain the VET courses and instructional supervision should be done by vocational experts/experienced instructors to ensure the quality of instruction and to ensure the skills and knowledge are imparted to the learners.

\section{Vocational Instructors}

Vocational educators are also known by instructors, trainers or instructors. Vocational instructors work mainly based on two competencies: teaching competence and competency related to specific work related vocational practice (Andersson and Kopsen, 2015).Therefore, Instructors in vocational education are required to have experience in their occupation, whether they went directly to university or whether they came from industry. The vocational instructors trained in such a way that they should appropriate for their occupation. Vocational instructor must use a competency based approach to instruction and this is the strength of the vocational education. Therefore, the VET training must be done by qualified experts with relevant work experience and practice must be done on equipment that used by industry. In addition, some of the training may have to be conducted on field and work site and with a flexible schedule to meet industry needs (Zenser and Lawrenz 2004). For this, VET institutions must recruit sufficient instructors to conduct VET courses and make ensure that workforce is well acquainted with the modern industry. Likewise, VET institutions should manage interchange and partnership between institutions and industry, so that instructors learn and update their knowledge and skills to enhance their pedagogical skills (Andersson and Kopson, 2015).

Like other teachers, vocational instructors are also expected to be knowledgeable about the subject they teach and they have identity related to their specific vocational subject. Modernization of vocational education and changes in working life demands vocational instructors to update their occupations. Therefore, to maintain their professionalism they should learn and practice knowledge and skills that meets current expectations. So best way to maintain their high quality professional's identity to continue contact with the industry to practice their vocational teaching subject that is useful and beneficial of professional development (Andersson and Kopsen, 2015).

\section{Conclusion}

In summary, the VET programs are designed to deliver knowledge and skills that directly related to getting a job at industry. Therefore, VET is a bridge between education and job market. There are many VET institutions around the world and offering varieties of different trade related VET courses. The study shows that vocational graduates are having problem with implementation of their learning in their jobs. As there is no proper coordination between VET training providers and job market. In addition, VET course are not regularly updated as per need of the job market, instructors are not technically sound and insufficient equipment in training institute. This questioned the quality of VET training. To solve this challenges, first of all there should be healthy coordination between VET institutes. As VET course prepare for job market, CBT approach should be considered while designing curriculum. Similarly, the experienced instructors and the environment of VET training providers play an important role for transferring skills and knowledge to the job market.

\section{References}

Acakpovi AK and Nutassey J (2015). Adoption of competency based education in TEVT Institutions in Ghan: a case study of Mechanical Engineering Department, Accra. International journal of training and education 7(7): 6469.DOI:10.5897/IJVTE2014.0150

Andersson P and Kopson, S. (2015). Continuing professional development of vocational teachers: participation in a Swedish national initiative. Empirical research in vocational education and training 29(8) 443-462. DOI: 10.1186/s40461-015-0019-3

Andin C and Ambotang S (2015) Student's satisfaction of the industrial skills enhancement program (INSEP). International journal of vocational education and training research. 1(2): 27-33. DOI:10.11648/j.ijvetr.20150102.13

Asian Development Bank (2014) Innovative Strategies in Technical Education and Vocational Training for Accelerated Human development in South Asia. Manila. Retrieved http://adb.org/sites/default/files/pub/2014/innovativestrategies-technical-vocational-education-training.pdf

Basnet KB (2012). Observation of technical education and vocational training (TEVT) in Nepal. Technical education and vocational training and development Journal 1(12): 321-339.

Blank WL (1982) Handbook for Developing Competency Based Approach to education and training, New York: PrenticeHall, Inc.

Council for Technical Education and Vocational Training (CTEVT) (2011) A Profile of Technical and Vocational Education Providers. Bhaktapur.

Council for Technical Education and Vocational Training (CTEVT) (2012) A Profile of Technical and Vocational Education Providers. Bhaktapur. 
Educational International (2009) Literature Review: What is Vocational Education and Training. Retrieved from download.ei/Docs/VET_Literature \%20AA.pdf

Gajural G and Ghimire SS (2012) Challenges and opportunities of technical Education and vocational training in Nepal. Nepal Intellectual Council Journal 11 (1).

Idiali E (2014) Creating an enabling environment for the teaching and learning of vocational and technical education in Nigeria and Sub-Sahara Africa. The Clute institute international academic conference. Retrieved from http://cluteinstitute.com/conferenceproceedings/2014SAPapers/Article\%20130.pdf

International Confederation for Midwifes (2012) Teaching and Learning in a Competency Based Curriculum. Retrieved from

http://www.internationalmidwives.org/assets/uploadsNE W.pdf

Lamsal HP (2012) Technical Vocational Education and Training: Global Experiences for Nepal. Technical and Vocational Education and Training Development Journal 1(2): 62-76.
Neupane BR and Pradhan HP (2014) Soft Skill Gaps in TEVT Curriculum Guides. Technical and Vocational Education and Training Development Journal 3(1): 12-23.

Ngang KT, Hashim NH and Yunus HM (2014) Novice teacher perceptions of the soft skills needed in today's workplace. Global conference on Contemporary Issues in Education. Las Vegas: Retrieved from www.ineer.org/Events/ICEE2007/papers/505.pdf

State of Queensland (2015). Vocational Education and Training in School. Retrieved from http://education.qld.gov.au/students/placement/vet/20\%3 259.pdf

TAFE (2008). Competency Based Training. Sydney. Retrieved from http://lrrpublic.cli.det.nsw.edu.au/lrrSecure/Sites/Web/13 289/\%ased.pdf

Zinser C and Lawrenz P (2004) New roles to meet industry needs: a look at the advanced technological education program. Journal of vocational education and research 29(2): 119234. $\quad$ Retrieved from https://scholar.lib.vt.edu/ejournals/JVER/v29n2/zinser.pd $\mathrm{f}$ 